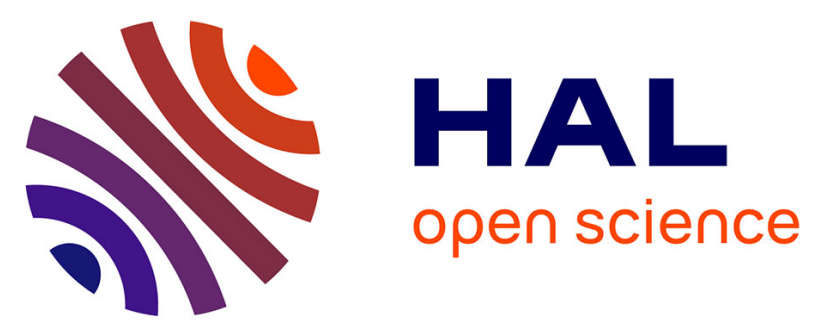

\title{
Specificity, $T$ cell receptor diversity and activation requirements of CD4+ and CD8+ clones derived from human melanoma-infiltrating lymphocytes
}

\author{
Marie-Christine Pandolfino, Christophe Viret, Nadine Gervois, Yannick
}

Guilloux, François Davodeau, Elisabeth Diez, Francine Jotereau

\section{To cite this version:}

Marie-Christine Pandolfino, Christophe Viret, Nadine Gervois, Yannick Guilloux, François Davodeau, et al.. Specificity, T cell receptor diversity and activation requirements of CD4+ and CD8+ clones derived from human melanoma-infiltrating lymphocytes. European Journal of Immunology, 1992, 22 (7), pp.1795-1802. 10.1002/eji.1830220719 . inserm-03350961

\section{HAL Id: inserm-03350961 https://www.hal.inserm.fr/inserm-03350961}

Submitted on 21 Sep 2021

HAL is a multi-disciplinary open access archive for the deposit and dissemination of scientific research documents, whether they are published or not. The documents may come from teaching and research institutions in France or abroad, or from public or private research centers.
L'archive ouverte pluridisciplinaire HAL, est destinée au dépôt et à la diffusion de documents scientifiques de niveau recherche, publiés ou non, émanant des établissements d'enseignement et de recherche français ou étrangers, des laboratoires publics ou privés. 
Content

highlights from

EULAR now available

\section{Using imaging to optimize patient care in psoriatic arthritis}

Catch up on Janssen's sponsored satellite symposium from this year's EULAR European Congress of Rheumatology, "To see is to believe? Guidance on using imaging to optimize patient care in psoriatic arthritis".

Access a curated collection of content, such as reports, infographics and more to help you apply optimal imaging techniques suitable for psoriatic arthritis diagnosis in clinical practice. Now available online.

\section{Access it all here}




\author{
Marie-Christine Pandolfino ${ }^{\wedge}$, \\ Christophe Viret ${ }^{\star}$, \\ Nadine Gervois ${ }^{\bullet}$, \\ Yannick Guilloux ${ }^{\star}$, \\ François Davodeau, \\ Elisabeth Diez ${ }^{\boldsymbol{A}}$ and \\ Francine Jotereau^
}

Unité 211 INSERM, Faculté des Sciences de Nantes, Nantes Laboratoire de Génétique Moléculaire des Eucaryotes du CNRS et Unité 184 INSERM, Strasbourg

\section{Specificity, $T$ cell receptor diversity and activation requirements of $\mathrm{CD4}^{+}$and $\mathrm{CD8}^{+}$clones derived from human melanoma-infiltrating lymphocytes*}

To try to understand the functional significance of human melanoma-infiltrating lymphocytes (TIL), a clonal analysis of the specificity, T cell receptor (TcR) diversity and activation requirements of these lymphocytes isolated from four different tumors was carried out. Supporting the presence of in vivo primed tumor-specific T lymphocytes in these four tumors, a high frequency of the CD8 ${ }^{+}$ and $\mathrm{CD} 4^{+}$clones, obtained from the TIL cultured for a few days with recombinant interleukin (rIL)-2 and autologous tumor cells, exhibited a restricted lysis or proliferation in response to the autologous tumor cell line. In contrast, no tumor-specific clone was obtained from freshly extracted TIL, suggesting that the frequency of tumor-specific effectors remained low in these tumors. Only the $\mathrm{CD}^{+}$clones lysed the autologous tumor cells and their activity was major histocompatibility complex MHC class I restricted. Significant expansion of $\mathrm{CD}^{+}$and $\mathrm{CD} 8^{+}$tumor-specific clones required regular restimulation by autologous melanoma cells but also the addition of exogenous IL-2 and of Epstein-Barr virus-transformed B feeder cells. Five different tumor-specific clones, three $\mathrm{CD} 8^{+}$and two $\mathrm{CD} 4^{+}$clones were identified in a single tumor on the basis of their TcR gene configuration. Together, these data suggest that a spontaneous and diverse immune response, mediated by tumor-specific $\mathrm{CD} 4^{+}$as well as $\mathrm{CD} 8^{+} \mathrm{T}$ lymphocytes, arises in most MHC-bearing human melanomas but that antigen-MHC complex presentation by tumor cells does not, at least in vitro, allow a significant proliferation of these lymphocytes.

\section{Introduction}

T cell-mediated protective immunity against tumors has been shown in animal models [1-7]. Some of these studies have also established the therapeutic efficacy of adoptively transferred tumor-specific $\mathrm{T}$ lymphocytes capable of proliferating in response to tumor cells, and secreting cytokines $[2-4,6,7]$. In cancer patients, despite the fact that tumorspecific T lymphocytes have been detected in some tumors, these cells obviously failed to mount an effective immune response. It would thus appear crucial to consider the reason for this failure in the context of recent attempts aimed at developing tumor therapies by tumor-infiltrating lymphocytes (TIL) transfer $[8,9]$. Functional analysis of tumor-specific $T$ cells have been done essentially with clones derived from the blood or lymph node lymphocytes of melanoma patients [10-14]. Repeated in vitro stimulation by autologous tumor cells and rIL-2 was required for the development of these clones, suggesting that they originated from rare precursors whose involvement in

[I 10157]

\footnotetext{
* This work was supported by funds from INSERM, by grant no. 6032 from the "Association pour la recherche sur le cancer" and by grants from the "Fédération Nationale des centres de Lutte Contre le Cancer".
}

Correspondence: Francine Jotereau, Unité 211 INSERM, plateau technique CHR, Quai Moncousu, F-44035 Nantes Cedex 01, France

Abbreviations: MLTC: Mixed lymphocyte tumor cell culture TIL: Tumor-infiltrating lymphocytes spontaneous immune responses is, therefore, questionable. The existence of a spontaneous anti-melanoma response was better supported by studies on polyclonal TIL. It has been shown that a significant proportion of human melanoma TIL developed tumor-specific lysis after a brief culturing with rIL-2 [15-17], suggesting that in vivo sensitized tumor-specific CTL are present inside these tumors. Surprisingly, only a few melanoma-specific TIL clones have been described so far $[16,18-21]$, so that the frequency and activation state of these cells as well as the possibility that $\mathrm{CD} 4^{+}$tumor-specific effectors exist in melanomas remains uncertain.

In an attempt to understand better the specificity, diversity and function of human melanoma TIL, we have carried out an analysis of these cells at the clonal level. We were able to isolate $\mathrm{CD}^{+}$as well as $\mathrm{CD} 8^{+}$tumor-specific clones from the four metastatic melanomas studied. Lytic activity, proliferative requirements and partial analysis of the diversity of these clones are described. Together the data obtained suggest that melanoma TIL are enriched in $\mathrm{CD}^{+}$ and $\mathrm{CD}^{+}$lymphocytes specific for tumor-associated antigens but that antigen presentation by tumor cells is not effective for inducing significant clonal expansion of these cells, at least in vitro.

\section{Materials and methods}

\subsection{Cell lines}

Melanoma cell lines M6, M16, M17, M18, M21 were established from metastatic tumor fragments cultured in RPMI 1640 containing $10 \%$ FCS. Beu and Dau melanoma 
lines were a gift of J.F. Doré (Lyon, France). NK and LAK target cell lines were K562 and Daudi, respectively. The EBV-transformed B cell line LAZ 388 was a gift of T Hercend (Institut Gustave Roussy, Villejiuf, France). The EBV-B cell line B17 was established by incubating PHAstimulated PBL from melanoma patient M17 with the culture supernatant of the EBV-producing cell line B95-8. Normal autologous target cells were $T$ lymphoblasts obtained by stimulating autologous polyclonal or clonal TIL with PHA-P (Difco, Detroit, MI) (1/1000), for 3 days

\subsection{Cloning of TIL}

TIL were obtained by culturing fragments of cutaneous metastatic melanomas (M6, M17) or melanoma-invaded lymph nodes (M16, M17, M18) with IL-2 medium consisting of RPMI 1640, $8 \%$ human AB serum (CTS, Nantes, France), $150 \mathrm{U} / \mathrm{ml}$ of recombinant IL-2 (rIL-2), gift from Roussel-Uclaf, Romainville, France) and antibiotics. This type of culture results in a mixed lymphocyte-tumor cell culture (MTLC) lasting as long as tumor cells survive in the culture. Duration of the MLTC culture was of 6,13 and 16 days for M18, M16 and M17 TIL, respectively. M6 TIL were cultured for 35 to 49 days before cloning but rapid proliferation and, therefore, culture splitting of TIL lead to the complete disappearance of tumor cells by day 12 . Limiting dilution culture of TIL was then carried out in 96-well microplates (Nunc, Roskilde, Denmark) at 0.3, 0.6, 3,6 and $30 \mathrm{TIL} /$ well together with irradiated feeder and stimulator cells $\left(2 \times 10^{4} \mathrm{LAZ}\right.$ cells and $1.5 \times 10^{3}$ melanoma cells) in $200 \mu \mathrm{l}$ rIL-2 medium containing PHA (1/1000). After $48 \mathrm{~h}$, and then twice weekly, half a volume of each well was replaced by fresh IL-2 medium. After 15 to 20 days of culture, each well was scored microscopically for growth. Proliferating T lymphocyte precursor (PTL-P) frequency was obtained by fitting a straight line describing the relationship between cell number/well and the logarithm of the fraction of nongrowing microcultures. According to the single-hit Poisson model, the cell dose containing on average one PTL-P, is given (on the abcissa) by the intercept of the straight titration line with the ordinate value 0.37 . Microcultures showing a probability of being clonal superior to $80 \%$ were transferred into new plates with freshly irradiated feeder and stimulator cells. Long-term clone growth was obtained by similarly transferring $2 \times 10^{3}$ or $5 \times 10^{3}$ lymphocytes/well every 2 or 3 weeks.

\subsection{Phenotypic analysis}

CD3, CD8 and CD4 expression by TIL and MHC class I and II antigen expression by melanoma cells was analyzed by indirect immunofluorescence with, respectively, OKT3, OKT8 (Ortho Diagnostic System, Raritan, NJ), and IOT4 (Immunotech, Marseille, France) $\mathrm{mAb}$ and ascites from W6/32 and 206 hybridomas (from ATCC and D. Charron, Institut des Cordeliers, Paris, France, respectively). Briefly, cells were treated at $4{ }^{\circ} \mathrm{C}$ for 30 min with mouse mAb, washed in PBS and incubated with $F\left(a b^{\prime}\right)_{2}$ fragments of goat anti-mouse $\mathrm{Ig}$ for an additional $30 \mathrm{~min}$. The labeled cells were analyzed with a fluorescence-activated cell sorter (FACScan Becton Dickinson, Grenoble, France).

\subsection{Proliferative response of TIL clones}

Proliferation of TIL clones was analyzed by transferring $2 \times 10^{3}-3 \times 10^{3} \mathrm{TIL} /$ well into new microplates with or without rIL-2 and with or without either autologous or allogeneic melanoma cells $\left(1.5 \times 10^{3}\right.$ irradiated cells $)$ or allogeneic EBV-B cells ( $2 \times 10^{5}$ irradiated LAZ cells), and by counting the lymphocytes 10 to 20 days later.

\section{5 $T$ cell cytotoxicity assay}

Cytotoxic activity was measured in a conventional 4-h assay against ${ }^{51} \mathrm{Cr}$-labeled cells $\left(\mathrm{Na}_{2}{ }^{51} \mathrm{CrO}_{4}\right.$, Oris Industrie, Gif sur Yvette, France). Briefly, $3 \times 10^{3}{ }^{51} \mathrm{Cr}$-labeled target cells were mixed with the effector cells at different effector to target $(\mathrm{E} / \mathrm{T})$ ratios $(20 / 1$ to $1 / 1)$ and incubated for $4 \mathrm{~h}$ at $37^{\circ} \mathrm{C}$. The spontaneous release of different targets ranged between $10 \%$ and $25 \%$ of the total label incorporated into the cells.

\subsection{Inhibition of cytotoxic activity of the CTL clones with mAb}

The mAb used for inhibition experiments were: OKT3 (anti-CD3), OKT8 (anti-CD8) and anti-MHC class I and II molecules (W6/32 and 206). The effect of these antibodies on the cytolytic activity of $\mathrm{T}$ cell clones was determined by mixing ${ }^{51} \mathrm{Cr}$-labeled target cells or TIL clones with serial dilutions of the $\mathrm{mAb}$ in a volume of $50 \mu \mathrm{l}$ for $1 \mathrm{~h}$ at $37^{\circ} \mathrm{C}$. Effector or target cells were then added, and the cytotoxicity was estimated as described above.

\subsection{Southern blot analysis of TIL DNA with TcR probes}

DNA was prepared from human placenta and from melanoma-specific clones derived from M17 TIL. DNA extracts were digested with Eco RI and Hind III (Boehringer Mannheim, Mannheim, FRG), electrophoresed in $0.7 \%$ agarose gel and transferred to nylon membranes (NHybond Amersham, Les Ulis, France) according to standard procedures. Hybridization probes were labeled by multipriming to a specific activity of $10^{9} \mathrm{cpm} / \mu \mathrm{g}$ [22]. Hybridizations of nylon blots were carried out at $65^{\circ} \mathrm{C}$ in $0.5 \mathrm{M} \mathrm{NaCl}, 0.005 \mathrm{M}$ sodium citrate, $0.2 \%$ polyvinylpyrrolidone, $0.2 \%$ BSA, $0.2 \%$ Ficoll, $0.5 \%$ SDS, $25 \mathrm{mM} \mathrm{Na-}$ $\mathrm{HPO}_{4} \mathrm{pH} 7,2 \mathrm{mM}$ EDTA, $100 \mu \mathrm{g}$ salmon sperm DNA. Hybridization was for $24 \mathrm{~h}$, followed by washing at $65^{\circ} \mathrm{C}$ in $0.3 \% \mathrm{NaCl}, 0.03 \mathrm{M}$ sodium citrate, $0.5 \% \mathrm{SDS}$. Filters were exposed to X-ray film at $-80^{\circ} \mathrm{C}$. Probes used were cDNA fragments $\mathrm{pC} \beta$, specific for the constant region of the $\beta$ chain of the TcR (a 700-bp Bam HI-Eco RI fragment) [23] and $\mathrm{pH} 60$ (a 700-bp Hind III-Eco RI fragment) containing the TRGJ1 gene segment and recognizing by homology the $\mathbf{J}_{\gamma} 2$ gene [24]. These DNA probes were kindly provided by M. P. Lefranc (U.A. CNRS 1191, Montpellier, France).

\section{Results}

\subsection{Tumor-specific lysis was restricted to the $\mathrm{CD8}^{+}$TIL}

TIL freshly isolated from melanomas M16 and M17 were cloned. None of the 68 clones tested was cytotoxic for the 
Table 1. Lytic activities of $\mathrm{CD} 8^{+}$and $\mathrm{CD} 4^{+}$clones from patient M17 CD8+ Clones

Tàrgets

M17 K.662 M16 M21 M18 Dau Beu Me14 Auto")

M17 d16

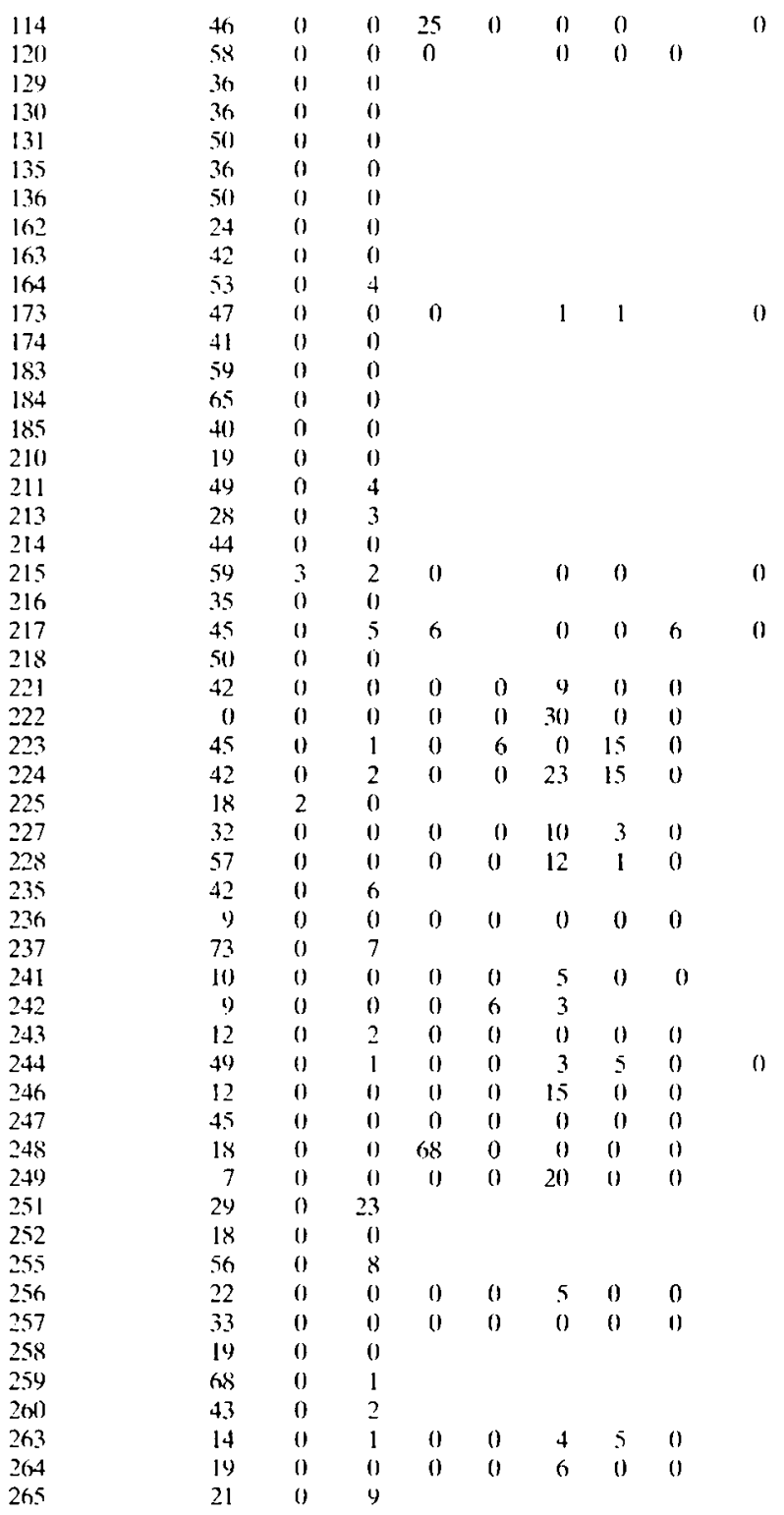

M17 d45

141

153

194

264

231

232

$\mathrm{CD}_{4}^{+}$Clones

\section{M17 d16}

125
123

123

226

M17 d45

147

2015

$$
\begin{array}{rrr}
0 & 0 & 0 \\
56 & 14 & 2 \\
0 & 0 & 7 \\
0 & 11 & 0
\end{array}
$$$$
\begin{array}{lllll}
0 & 0 & 26 & 3 & 0
\end{array}
$$$$
0
$$
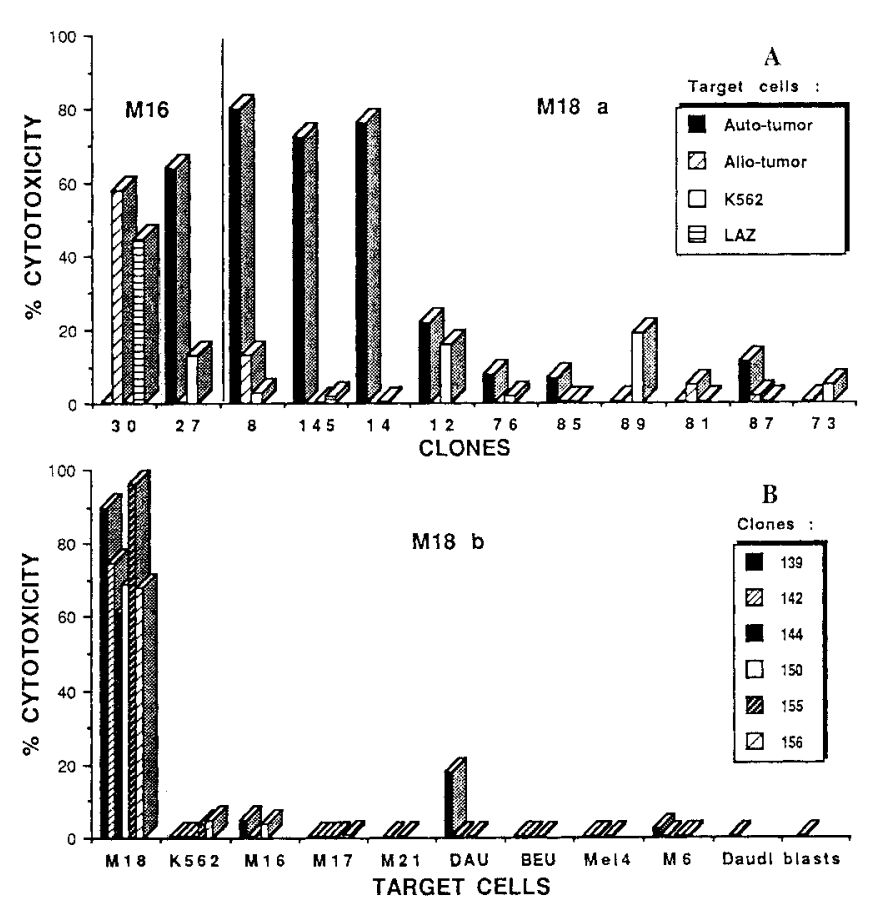

Figure 1. Percent lytic activity of $\mathrm{CD}^{+}$clones derived from M16 and M18 TIL, on autologous and allogeneic target cells at an E/T ratio of 20/1. Clones whose activity is shown on Fig. 1A were grown on allogeneic feeder and stimulator cells (LAZ and PBL), in the absence of a stimulation by autologous melanoma cells; clones on Fig. 1B were obtained on autologous tumor cells and allogeneic LAZ cells. lytic activity against the autologous tumor cells (Fig. 1 and Table 1). Since these clones did not lyse K562, Daudi, autologous EBV-B cells, autologous T cell blasts and most specific. Data on lytic activity of clones derived from TIL cultured with IL-2 for 43 days have been reported before [18]. Two additional clonings of M6 TIL were done. As shown on Table 2, all M6 CD8 ${ }^{+}$clones were lytic and tumor specific. At an E/T ratio of 20/1, lysis by M17 $40 \%$ to $84 \%$ and that by M18 clones from $63 \%$ to $96 \%$. Since LAK cells lysed M6 cells significantly better than M17 cells (data not shown) this may be related to the different sensitivity to lysis of the melanoma lines. Auto-
logous melanoma lysis by TIL clones remained stable throughout long-term culture. One of the few $\mathrm{CD}^{+}$clones which did not kill the autologous melanoma cell line (clone M16.30), was shown to kill both the allogeneic EBV-B cells
(LAZ), used as feeders, and one allogeneic melanoma cell line (Fig. 1). This clone was, therefore, presumably specific for allogeneic MHC determinants shared by these two cell lines.

Out of $71 \mathrm{CD}^{+}$clones 69 were not lytic at all (data not shown). Soon after cloning, two $\mathrm{CD}^{+}$clones had a lytic activity which was the highest against the M17 autologous tumor cells (Table 1). This activity, however, disappeared

autologous melanoma. These clones did not kill K562 and three allogeneic melanoma lines (data not shown). Eight clonings were then performed from TIL previously cultured for 6 to 49 days with rIL-2 and in the presence of autologous
tumor cells for 6 to 16 days. In striking contrast to previous clonings, most $\mathrm{CD} 8^{+}$clones obtained exhibited a stable 
during subculture so that its specificity could not be confirmed. The number of $\mathrm{CD}^{+}$and $\mathrm{CD}^{+}$clones obtained from each cloning which killed specifically the autologous melanoma with a lytic activity greater than $10 \%$ (at an E/T ratio of 20/1) is summarized in Table 2.

\subsection{All CTL clones and about half of the $\mathrm{CD}^{+}$clones proliferated specifically in response to autologous melanoma cells}

Specificity of TIL-derived clones was further analyzed by studying their proliferative response to autologous tumor cells. For some clones, this response was assessed soon after cloning, using cells removed from the maintenance culture 7 to 15 days after a transfer on autologous melanoma cells and EBV-B cells. As shown on Fig. 2, a majority of CTL clones grew exclusively in the presence of autologous tumor cells. A few clones which proliferated as well on allogeneic melanoma cells, 4 weeks after cloning, became dependent upon restimulation by autologous tumor cells for their growth at a later transfer (data not shown). Typical proliferative responses of $\mathrm{CD} 4^{+}$clones are shown in Fig. 3. Out of $19 \mathrm{CD}^{+}$clones tested 9 grew exclusively in the presence of autologous melanoma cells (Fig. 3A). The other clones also grew on most allogeneic melanoma cells and EBV-B cells (Fig. 3B). Some of these clones proliferated as well on the LAZ EBV cell line alone and were, therefore, probably specific for allogeneic class II MHC antigen of these cells. $\mathrm{CD}^{+}$clones, which proliferated exclusively in the presence of autologous melanoma cells, are likely to be specific for autologous tumor-associated antigens since they did not proliferate in response to autologous lymphoblasts expressing MHC class II Ag, plus EBV-B feeder cells. As inferred from cytotoxic and proliferation data, the four melanoma cell lines used in this study were shown to express class I and class II MHC molecules (data not shown).

\subsection{Activation requirements of tumor-specific $\mathrm{CD4}^{+}$and $\mathrm{CD8}^{+}$TIL-derived clones}

In vitro activation requirements of tumor-specific clones were further analyzed by culturing these clones with or

Table 2. Tumor-specific lysis was essentially restricted to $\mathrm{CD} 8^{+}$ clones

\begin{tabular}{llc} 
TIL & \multicolumn{2}{c}{ CD4 } \\
& & $\mathrm{CD}^{+}$ \\
M6 d35 & & \\
M6 d43 & $0 / 19^{\mathrm{b})}$ & $\mathrm{d}$ \\
M6 d43 & $0 / 10$ & $2 / 2$ \\
M6 d49 & $0 / 21$ & $11 / 11$ \\
M16 d13 & $0 / 1$ & $7 / 7$ \\
M17 d16 & $0 / 7$ & $1 / 2$ \\
M17d45 & $1 / 4$ & $50 / 54$ \\
M18d6a & $1 / 2$ & $6 / 7$ \\
M18 d6b & $0 / 5$ & $3 / 10$ \\
& $0 / 3$ & $6 / 6$ \\
& $2 / 71$ & $85 / 96$
\end{tabular}

a) Duration of the TIL culture before cloning.

b) Fraction of the clones which exhibited a specific lytic activity on autologous tumor cells $(>10 \%$ at an $\mathrm{E} / \mathrm{T}$ ratio $20 / 1)$.

c) Clonings performed on allogeneic feeder cells (PBL +EBV-B cells). The other clonings were done with autologous tumor cells and allogeneic EBV-B cells.

d) No $\mathrm{CD}^{+}$clone obtained.
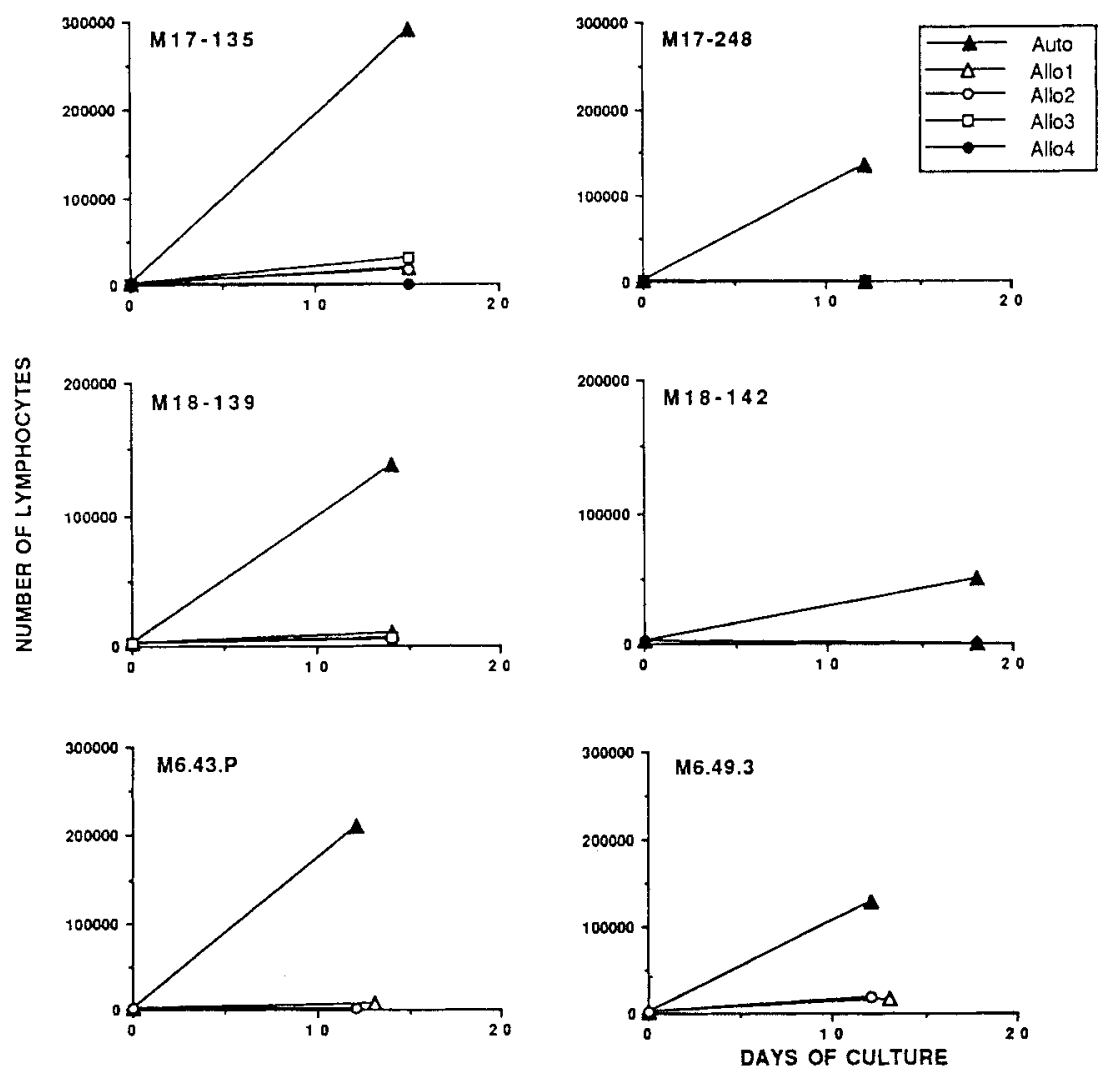

Figure 2. Proliferative responses of six tumor-specific CTL clones, obtained from M6, M17 and M18 TIL, cultured either with autologous tumor cells and $\mathrm{LAZ}(\mathbf{A})$ or allogeneic melanoma cells and LAZ $(\triangle, \bigcirc, \square, \bullet)$. Indication of statistical variation was not given since it concerned only the response to autologous tumor cells, which was quite variable from one experiment to another, due to the complexity of the culture system. 

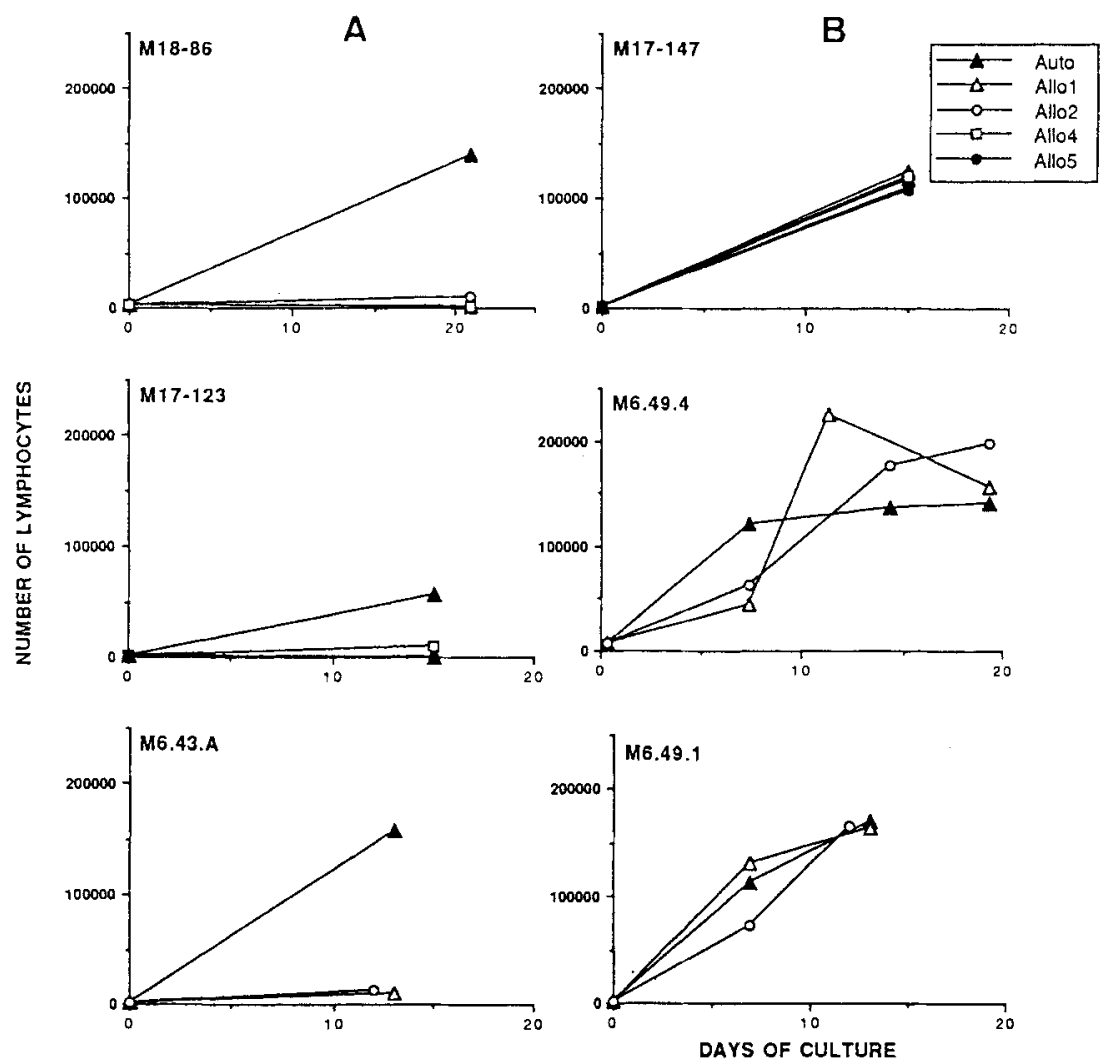

Figure 3. Proliferative responses of six $\mathrm{CD}^{+}$ clones, obtained from M6, M17 and M18 TIL on either autologous tumor cells and LAZ (A) or allogeneic melanoma cells and LAZ $(\triangle, \bigcirc, \square, \bigcirc)$. (A) tumor-specific clones; (B) tumor-nonspecific clones.

without feeder (LAZ) or stimulator cells (autologous melanoma cells) and exogenous IL-2. Data on Fig. 4 confirm that clonal proliferation was, for most clones, strictly dependent upon the presence of autologous tumor cells: growth was never observed in response to EBV-B cells, allogeneic melanoma cells, or rIL-2. Clonal expansion, in response to autologous melanoma cells, was also strictly dependent upon the addition of exogenous $\mathrm{IL}-2$ and, for two clones, also upon the addition of EBV-B cells.

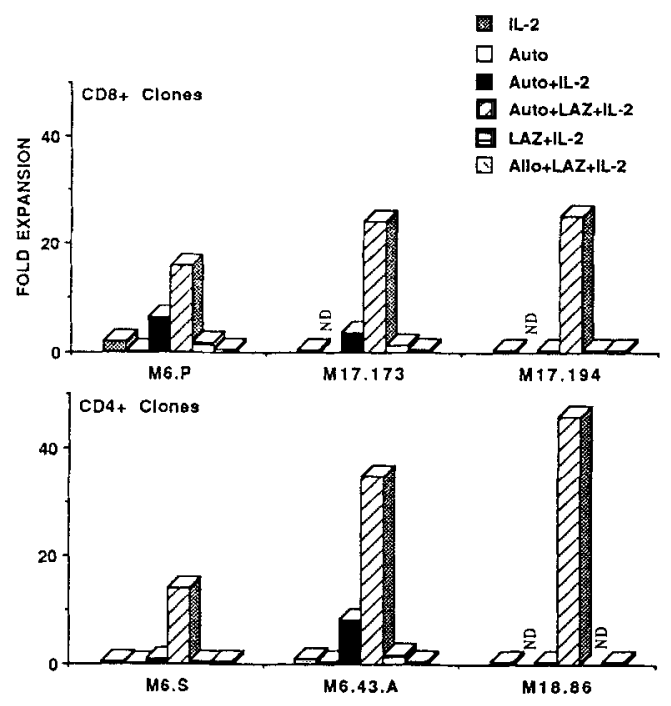

Figure 4. Proliferative responses of thre $\mathrm{CD}^{+}$and three $\mathrm{CD} 8^{+}$ melanoma-specific clones to IL-2, LAZ (feeder) cells and (or) autologous or allogeneic melanoma cells. The values are from one expansion experiment which is representative of two or four different experiments.
Proliferation of the other three clones in response to autologous melanoma cells and rIL-2, although significant, was strongly increased by EBV-B cells.

\subsection{TcR involvement and MHC restriction of tumor cell recognition by $\mathrm{CD8}^{+}$clones}

To establish whether the TIL-derived CTL clones recognized and killed autologus melanoma cells through TcR complex-MHC interaction, antibodies specific for the CD3 complex ( $\varepsilon$ chain), for the CD8 molecule and for public epitopes of class I or class II MHC molecules were assayed in inhibition experiments of clonal proliferation or of melanoma lysis. When M17 and M18 melanoma cells were preincubated with an antibody specific for MHC class I molecules (W6/32) lysis of these cells by autologous CD $8^{+}$ clones was suppressed, while an anti-MHC class II mAb did not inhibit lysis (Fig. 5). Similarly, when these antibodies were added to the culture of the M18.139 clone proliferation was completely blocked only by the anti-MHC class I $\mathrm{mAb}$. The anti-class II antibody also interfered with clonal expansion, but significantly less than the anti-class I (data not shown). Anti-CD3 partially inhibited tumor lysis by all the TIL clones, whereas, anti-CD8 antibody variably affected the lytic activity of different clones (Fig. 5). Type-1, -2 and -3 M17 CTL clones (identified below by their TcR gene configuration) showed a complete, partial or no CD8 dependency for their lysis, respectively. The M17 114 clone which was shown to be a mixture of type-1 and -2 clones had a susceptibility intermediate to that of both clones. Involvement of CD3, CD8, TcR and HLA class I molecules in the lysis of $\mathrm{M} 6$ melanoma cells by $\mathrm{M} 6 \mathrm{CD}^{+}$ clones have been shown previously [20]. 


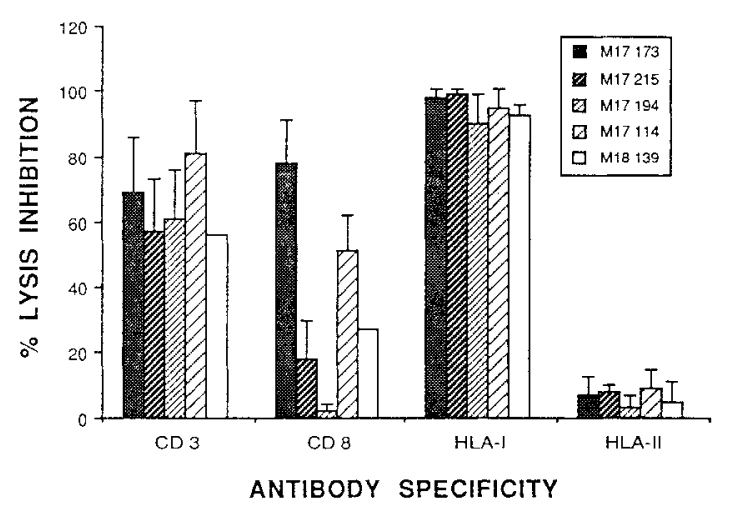

Figure 5. Involvement of relevant T cell surface molecules: CD3 and CD8 and of melanoma MHC molecules in the lysis of melanoma cells M17 and M18 by autologous TIL clones. Percentage of inhibition was calculated by comparing the lytic activities obtained in the presence of $\mathrm{mAb}$ with the lysis obtained from effectors and targets incubated with medium alone. The data represent the mean ( \pm SD) of three independent experiments. The assays were performed with a hybridoma supernatant for anti-CD3 and with 1/100 ascites fluid for other antibodies.

\subsection{TcR diversity among melanoma-specific $\mathrm{CDB}^{+}$and $\mathrm{CD4}^{+}$clones}

The fact that 53 tumor-specific CTL clones have been obtained from melanoma M17, led us to investigate the diversity of these clones. TcR $\beta$ and $\gamma$ gene rearrangements of 27 of these clones were analyzed by Southern blotting using a $\mathrm{J}_{\gamma}$ and $\mathrm{C}_{\beta}$ probes. As shown on Figs. 6 and 7 , three different TcR gene patterns were identified. Patterns 1,2 and 3 were found in 6,15 and 6 clones, respectively. A few clones exhibiting $\beta$ rearrangements typical of pattern 1 or 3 appeared to be mixed with a clone of pattern 2 since in addition to the appropriate $\gamma$ gene pattern they also exhibited $\gamma$ rearrangements of sizes compatible with $\gamma$ gene pattern 2 (Fig. 7). Two $\mathrm{CD} 4^{+}$tumor-specific M17 clones each exhibited one typical TcR $\beta$ and $\gamma$ gene configuration

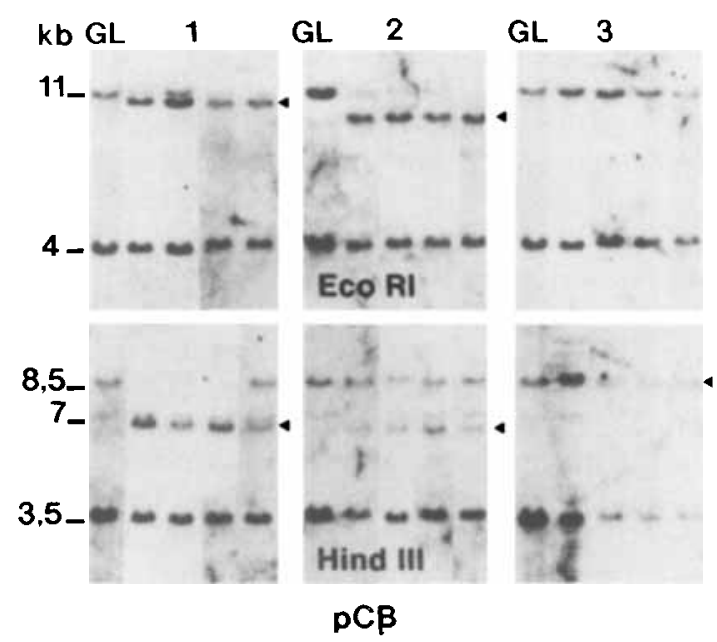

Figure 6. Southern blot analysis with the $\mathrm{pC} \beta$ probe of Eco RI and Hind III digests of germ-line DNA (GL) (from autologous melanoma cells) and DNA from 12 melanoma-specific CD $8^{+} \mathrm{M} 17$ clones. Three different TcR gene patterns, 1, 2 and 3, shown here, were identified. Sizes of the germ-line fragments is given in $\mathrm{kb}$. Rearranged bands typical of type 1,2 and 3 clones are indicated by a black triangle.

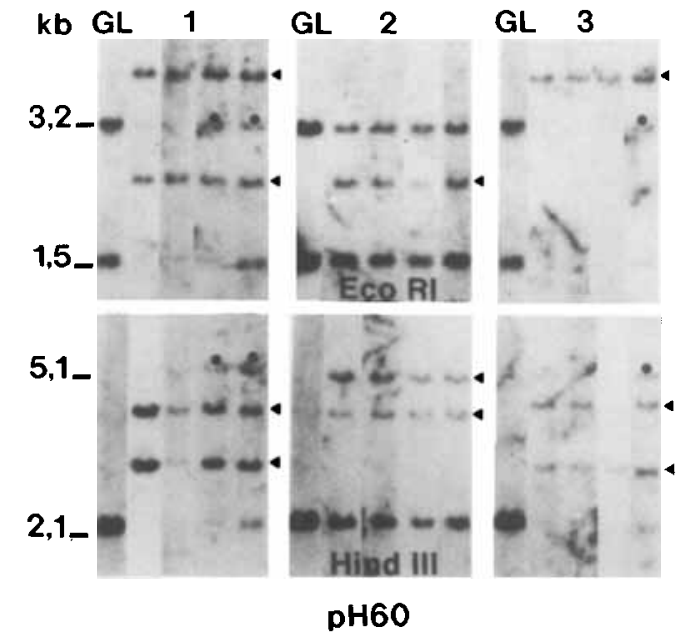

Figure 7. Southern blot analysis of the same DNA as in Fig. 6 with the $\mathrm{pH} 60$ probe. Triangles indicate they $\gamma$ TcR gene rearrangements typical of type 1,2 and 3 clones. Black circles show supernumerary $V_{\gamma}$ gene rearrangements, typical of clone 2, which indicate that these cultures were biclonal and contained either clone 1 and 2 or clone 3 and 2 .

(data not shown) and were, therefore, different from each other.

\section{Discussion}

The data reported here strongly suggest that in vivo primed tumor-specific $\mathrm{CD}^{+}$and $\mathrm{CD} 4^{+}$TIL are consistently present inside human melanomas. This is supported by the very high frequency of tumor-specific clones which have been obtained from melanoma TIL of four different patients and which were previously submitted to a brief culturing with rIL-2 and autologous tumor cells. The fact that tumor-specific CTL clones were not detected in contrast among TIL freshly isolated from two of these patients suggests that the frequency of tumor-specific lymphocytes remains low in these tumors. Culture with rIL-2 and autologous tumor cells probably increased the frequency of these cells by selectively favoring the growth of pre-activated tumor-specific TIL. Studies on polyclonal TIL also support a similar interpretation [15-17]. An alternative hypothesis is that melanoma-specific TIL were artificially expanded from a few tumor-reactive lymphocytes present among every polyclonal lymphocyte population. The present data do not support this hypothesis since the frequency of tumor-specific clones obtained from TIL appears to be higher than that obtained from the PBL or lymph node lymphocytes of melanoma patients $[10-13,25]$. Long-term in vitro stimulation of PBL with autologous tumor cells was required to generate tumor-specific clones with a relatively low efficacy $(10 \%-40 \%$ of the clones, for review see [21]), whereas after a much shorter culture period with autologous melanoma cells and IL-2, two TIL populations yielded more than $90 \%$ tumor-specific $\mathrm{CD} 8^{+}$ clones.

In contrast to previous reports on TIL- or PBL-derived clones (for a review see [26]) none of our clones exhibited a broad cytolytic profile with the exception of two $\gamma / \delta$ clones (unpublished data). Most $\mathrm{CD}^{+}$clones $(88 \%)$ killed the 
autologous melanoma line, but did not kill $\mathrm{K} 562$, other autologous target cells and a few MHC class I-expressing allogeneic melanoma lines. These clones were, therefore, likely specific for autologous melanoma-associated antigens. Surprisingly, despite the constant addition of LAZ cells in the cultures, only $6 \%$ of the $\mathrm{CD} 8^{+}$clones produced appeared to be reactive with this allogeneic EBV-B cell line. This suggests that tumor-specific lymphocytes were already the dominant population among TIL cultured for a few days with autologous tumor cells and IL-2. Reinforcing the specificity of melanoma recognition by $\mathrm{CD} 8^{+} \mathrm{TIL}$ clones, antibodies specific for a common MHC class I determinant or for the CD3 $\varepsilon$ chain, but not those directed against class II MHC antigen, inhibited the lysis of autologous melanoma cells. Furthermore, from their second or third transfer after cloning most tumor-specific $\mathrm{CD}^{+}$ clones proliferated exclusively in the presence of autologous melanoma cells and EBV-B cells.

About half the $\mathrm{CD}^{+}$clones also proliferated on autologous but not on allogeneic melanoma cells (together with LAZ feeder cells) and were, therefore, presumably tumor specific. Specificity of the remaining $\mathrm{CD}^{+}$clones was not determined.

Among 27 melanoma-specific CTL clones derived from M17 melanoma, three clones differing by their $\gamma$ and $\beta$ TcR gene configuration were identified. The five different rearranged $\beta$ bands identified in these three clones were of different sizes which indirectly suggests that the functional $V_{\beta}$ genes used by these clones were different. Given the relatively small number of clones analyzed and the fact that some clones could have been lost during the culture performed before cloning, it is possible that there were more than three melanoma-specific CTL clones in this tumor. The two tumor-specific $\mathrm{CD} 4^{+}$clones extracted from M17 melanoma also had different rearrangements (data not shown) and were, therefore, distinct clones. Furthermore, it has to be stressed that melanoma lines were used as target cells in this study, which possibly restricts the tumor antigen diversity present in vivo. A diverse repertoire of $\mathrm{TcR}$ is, therefore, used by TIL to recognize the autologous melanoma. Furthermore, the CTL clones may have had different affinity for melanoma cells since they exhibited either complete, partial or no dependency on CD8 for their lysis.

Since different rearrangements can generate receptors with similar specificity, it is not known whether different TIL clones recognize a unique or different antigen(s). Elegant studies on the specificity of CTL clones obtained from the PBL of melanoma patients stimulated in vitro by mutagenized or immunoselected tumor variants showed that three to six different epitopes of these tumor cells can be recognized by autologous $\mathrm{T}$ lymphocytes $[12,13,27]$. It remains to be established whether these PBL clones have the same repertoire and functional properties as TIL locally sensitized by tumor cells.

The reason why tumor-specific TIL apparently present in most human melanomas fail to control tumor growth is not known. It has been shown recently that self-reactive $\mathrm{T}$ lymphocytes, not eliminated by intrathymic selection, can be renderred nonresponsive to autologous antigens (a state called anergy; $[28,29])$. Clonal anergy appears to result from interaction of the TcR with antigen-MHC complex in the absence of a co-stimulatory signal. Anergic lymphocytes show a long-lasting inability to produce IL-2 in response to normal antigenic stimulation. They express, however, the IL-2 receptor gene and are responsive to exogenous $\mathrm{IL}-2$ [30]. We observed that $\mathrm{CD}^{+}$and $\mathrm{CD} 8^{+}$ melanoma-specific clones proliferated moderately or not at all in response to melanoma cells and rIL-2, whereas good proliferation was obtained by adding allogeneic EBV-B cells, which are known to express a number of accessory molecules. We also recently showed that these feeder cells strongly stimulated in vitro proliferation of polyclonal melanoma TIL in response to rIL-2, allowing consistent manifold expansion of tumor-specific cytotoxic lymphocytes from most human melanomas [31]. These data suggest that peptide-MHC recognition, on the surface of autologous tumor cells, do not activate $\mathrm{CD}^{+}$and $\mathrm{CD} 8^{+}$melanoma-specific TIL clones efficiently. Furthermore the complete lack of proliferation of melanoma-specific TIL clones in response to a stimulation by tumor cells and EBV-B cells in the absence of exogeneous IL-2 strongly suggests that they do not produce IL-2 by themselves. It is, therefore, a working hypothesis that antigen presentation by melanoma cells to TIL inside tumors, independently of APC presentation, could render tumor-specific lymphocytes anergic. This would explain why the frequency of these cells remains low among TIL and account for the absence of an effective immune response against some tumors despite MHC class I and II antigen expression on tumor cells and the presence of $\mathrm{CD}^{+}$and $\mathrm{CD}^{+}$TIL capable of recognizing tumorassociated antigens. This would have important implications for the development of tumor immunotherapies.

We are grateful to the Roussel-Uclaf company for providing recombinant $I L-2$. We also thank A. Hivonnait for technical assistance.

Received December 2, 1991; in final revised form March 20, 1992.

\section{References}

1 Kripke, M. L., Adv. Cancer Res. 1981. 34: 69.

2 Cheever, M. A., Thompson, D. B., Klarnet, J. P. and Greenberg, P. D., J. Exp. Med. 1986. 163: 1100.

3 Spiess, P. J., Yang, J. C. and Rosenberg, S. A., J. Natl. Cancer. Inst. 1987. 79: 1067

4 Chou, T., Bertera, S., Chang, A. E. and Shu, S., J. Immunol. 1988. 141: 1775.

5 Fearon, E. R., Pardoll, D. M., Itaya, T., Golumbek, P., Levitsky, H. I., Simons, J. W., Karasuyama, H., Vogeistein, B. and Fost, P., Cell 1990, 60: 397.

6 Lynch, D. H. and Miller, R. E., Eur. J. Immunol. 1991. 21: 1403.

7 Evans, R., Duffy, T. M. and Kamdar, S. J., Eur. J. Immunol. 1991. 21: 1815.

8 Rosenberg, S. A., Packard, B. S., Aebersold, P. M., Solomon, D., Topalian, S. L., Toy, S. T., Simon, P., Lotze, M. T., Yang, J. C., Seipp, C. A., Simpson, C., Carter, C., Bock, S., Schwartzentruber, D., Wei, J. P. and White, D. E., N. Engl. J. Med. 1988. 319: 1676.

9 Kradin, R. L., Kurnick, J. T., Lazarus, D. S., Preffer, F. I., Dubinettt, S. M., Pinto, C. E., Gifford, J. G., Davidson, E. D., Grove, B., Callahan, R. J. and Strauss, H. W., Lancet 1989. i: 577.

10 Herin, M., Lemoine, C., Weynants, P., Vessière, F., Pel, A. V., Knuth, A., Devos, R. and Boon, T., Int. J. Cancer 1987. 39: 390. 
11 Mukherji, B., Guha, A., Chakraborty, N. G., Sivanandham, M., Nashed, A. L., Sporn, J. R. and Ergin, M. T., J. Exp. Med. 1989. 169: 1961.

12 Degiovanni, G., Lahaye, T., Hérin, M., Hainaut, P. and Boon, T., Eur. J. Immunol. 1988. 18: 671.

13 Knuth, A.,Wolfel, T., Klehmann, E., Boon, T. and Meyer zum Büschenfelde, K. H., Proc. Natl. Acad. Sci. USA 1989. 86: 2804.

14 Wölfel, T., Klehmann, E., Müller, C., Schütt, K. H., Meyer zum Büschenfelde, K. H. and Knuth, A., J. Exp. Med. 1989. 170: 797 .

15 Itoh, K., Tilden, A. B. and Balch, C., Cancer Res. 1986. 46: 3011.

16 Itoh, K., Platsoucas, C. D. and Balch, C. M., J. Exp. Med. 1988. 168: 1419.

17 Topalian, S. L., Solomon, D. and Rosenberg, S. A., J. Immunol. 1989. 142: 3714.

18 Anichini, A., Mazzocchi, A., Fossati, G. and Parmiani, G., $J$. Immunol. 1989. 142: 3692 .

19 Yamada, T., Holmes, E. C. and Golub, S. H., Cancer Commun. 1990. 2: 113

20 Gervois, N., Heuzé, F., Diez, E. and Jotereau, F., Eur. $J$. Immunol. 1990. 20:825.
21 Platsoucas, C. D., Cancer Metastasis Rev. 1991. 10: 151.

22 Feinberg, A. P. and Vogelstein, B., Anal. Biochem. 1983. 132: 6.

23 Sims, J. E., Tunnacliffe, A., Smith, W. J. and Rabbitts, T. H., Nature 1984. 312: 541.

24 Lefranc, M. P., Foster, A. and Rabbitts, T. H., Nature 1986. 319: 420 .

25 Anichini, A., Fossati, G. and Parmiani, G., Immunol. Today 1985. 35: 683.

26 Anichini, A., Fossati, G. and Parmiani, G., Immunol. Today 1987. 8: 385.

27 Van Den Eynde, B., Hainaut, P., Hérin, M., Knuth, A., Lemoine, C., Weynants, P., Van Der Bruggen, P., Fauchet, R. and Boon, T., Int. J. Cancer 1989. 44: 634.

28 Ramsdell, F., Lantz, T. and Fowlkes, B. J., Science 1989. 246: 1038.

29 Rammensee, H., Kroschewski, R. and Frangoulis, B., Nature 1989. 339: 541

30 Jenkins, M. K., Pardoll, D. M., Mizuguchi, J., Quill, H. and Schwartz, R. N., Immunol. Rev. 1987. 95: 113.

31 Jotereau, F., Pandolfino, M. C., Boudart, D., Diez, E., Dreno, B., Douillard, J. Y., Muller, J. Y. and Lemevel, B., J. Immunother. 1991.10: 405. 